\title{
Kualitas Hidup Lansia Pengguna Gigi Tiruan di Desa Toulimembet Kecamatan Kakas
}

\author{
${ }^{1}$ Veren T. Worang \\ ${ }^{1}$ Krista V. Siagian \\ ${ }^{2}$ Lydia E. N. Tendean \\ ${ }^{1}$ Program Studi Pendidikan Dokter Gigi Fakultas Kedokteran \\ ${ }^{2}$ Bagian Biologi Fakultas Kedokteran \\ Universitas Sam Ratulangi Manado \\ Email: verenworang98@gmail.com
}

\begin{abstract}
Good quality of life is very desirable for elderly to fulfill a meaningful, happy, and useful life. The loss of whole or partial teeth has the same effect as disability. Well-made artificial teeth can improve mastication, pronunciation, as well as aesthetic function, maintain healthy tissue, and prevent further damage to the structures in oral cavity. This study was aimed to determine the quality of life of elderly denture users at Desa Toulimembet, Kakas. This was a descriptive study with a cross sectional design. Population consisted of elderly denture users as many as 195 people meanwhile samples were obtained by using purposive sampling techniques. The instrument used in this study was GOHAI questionnaire. The results showed that there were 77 elderly denture users in this study. The assessment of quality of life based on the dimensions of physical function, namely limiting the amount of food, experiencing problems when chewing, and difficulty, was categorized as quite good; based on the dimensions of pain and discomfort which were taking drugs to relieve pain, felt uncomfortable, and was sensitive to food were classified as quite good category; and based on the dimensions of psychosocial aspects namely limiting oneself, being anxious or worried, and feeling insecurity was classified as quite good category. Generally, the assessment of quality of life based on the three dimensions was quite good. In conclusion, the quality of life of elderly denture users at Desa Toulimembet, Kakas was quite good.
\end{abstract}

Keywords: denture users, elderly, quality of life

\begin{abstract}
Abstrak: Kualitas hidup yang baik merupakan sesuatu yang sangat diinginkan lansia agar dapat menikmati masa tuanya dengan penuh makna, membahagiakan, dan berguna. Hilangnya seluruh gigi atau sebagian berefek yang sama dengan kecacatan hidup. Gigi tiruan diharapkan dapat memperbaiki fungsi pengunyahan, pengucapan, estetis, menjaga kesehatan jaringan serta mencegah kerusakan lebih lanjut dari struktur organ dalam rongga mulut. Penelitian ini bertujuan untuk mengetahui kualitas hidup lansia pengguna gigi tiruan di Desa Toulimembet Kecamatan Kakas. Jenis penelitian ialah deskriptif dengan desain potong lintang. Populasi penelitian ialah lansia pengguna gigi tiruan sebanyak 195. Responden berjumlah 77 lansia diperoleh dengan teknik purposive sampling. Instrumen yang digunakan ialah kuesioner GOHAI. Hasil penelitian menunjukkan bahwa penilaian kualitas hidup berdasarkan dimensi fungsi fisik yaitu, membatasi jumlah makanan, mengalami masalah saat mengunyah dan kesulitan tergolong kategori cukup baik; dimensi nyeri dan ketidaknyamanan yaitu mengonsumsi obat-obatan untuk menghilangkan nyeri, merasa tidak nyaman dan sensitif terhadap makanan tergolong kategori cukup baik; serta dimensi aspek psikososial yaitu membatasi diri, cemas atau kwatir, dan tidak percaya diri tergolong kategori cukup baik. Secara keseluruhan penilaian kualitas hidup berdasarkan 3 dimensi tersebut tergolong cukup baik. Simpulan penelitian ini ialah kualitas hidup lansia pengguna gigi tiruan di Desa Toulimembet Kecamatan Kakas tergolong cukup baik.
\end{abstract}

Kata kunci: Pengguna gigi tiruan, lansia, kualitas hidup 
Semua manusia akan mengalami masa lansia dan menjadi tua adalah proses alami yang tidak dapat dihindari oleh setiap makhluk hiudp, proses ini akan berjalan secara terus menerus seiring berjalannya perjalanan kehidupan. Menurut UndangUndang Republik Indonesia No. 13 Tahun 1998 pasal 1 ayat 2 tentang kesejahteraan lansia, lansia adalah seorang yang telah mencapai usia enam puluh tahun ke atas. ${ }^{1}$

Proporsi jumlah lansia terus berkembang di seluruh dunia, terutama di negara berkembang. Pertumbuhan jumlah lansia cenderung lebih cepat dibandingkan kelompok usia lainnya. Indonesia merupakan salah satu negara berkembang dan mengalami jumlah ledakan penduduk lansia. Sulawesi Utara sebagai salah satu provinsi di Indonesia memiliki jumlah lansia sebesar $8,45 \%$ dan menduduki posisi ke-5 jumlah lansia terbanyak dibanding provinsi lainnya. ${ }^{2.3}$

Masa lansia banyak terjadi penurunan kemampuan akal fisik yang salah satunya karena proses menua. Proses menua adalah suatu proses menghilangnya secara perlahan kemampuan jaringan untuk memperbaiki diri atau mengganti dan mempertahankan fungsi normalnya. ${ }^{4}$ Banyaknya penduduk yang berusia lansia akan meningkatkan akan pembuatan gigi tiruan akibat besarnya risiko kehilangan. Hilangnya seluruh gigi atau sebagian mempunyai efek yang sama terhadap kecacatan hidup. Gigi tiruan pada hakekatnyya dibuat untuk memperbaiki fungsi pengunyahan, pengucapan, estetis, menjaga kesehatan jaringan serta mencegah kerusakan lebih lanjut dari struktur organ dalam rongga mulut. ${ }^{5}$

Kualitas hidup merupakan kesempatan individu untuk dapat hidup hidup nyaman, mempertahankan keadaan fisiologis sejalan dengan keadaan psikologis dalam kehidupan sehari-hari. Quality of Life (QoL) berdasarkan definisi WHO adalah persepsi individu di kehidupan mereka dalam konteks kebudayaan dan norma kehidupan mereka dalam konteks kebudayaan dan norma kehidupan serta hubungannya dengan tujuan, harapan, standar dan perhatian mereka terhadap hidupnya. ${ }^{6}$
Hidup yang berkualitas merupakan sesuatu yang sangat diinginkan lansia. Hidup lansia yang berkualitas merupakan kondisi fungsional lansia pada kondisi optimal sehingga mereka bisa menikmati masa tuanya dengan penuh makna, membahagiakan dan berguna. ${ }^{7}$ Pemakain gigi tiruan diharapkan dapat meningkatkan rasa percaya diri dalam bersosialisasi dan dapat meningkatkan kualitas hidup lansia.

Penelitian ini dilakukan untuk mengetahui kualitas hidup lansia pengguna gigi tiruan di Desa Toulimembet Kecamatan Kakas.

\section{METODE PENELITIAN}

Penelitian ini dilakukan pada bulan Mei 2019 di Desa Toulimembet Kecamatan Kakas, Kabupaten Minahasa, Provinsi Sulawesi Utara. Jenis penelitian ini ialah deskriptif dengan desain potong lintang. Populasi penelitian ini yaitu seluruh lansia di Desa Toulimembet yang berjumlah 195 orang dengan besar sampel 77 lansia dihitung menggunakan rumus Slovin. Teknik pengambilan sampel yaitu purposive sampling.

Kriteria inklusi ialah: menggunakan gigi tiruan dan bersedia mengikuti seluruh prosedur kegiatan penelitian dengan penandatangan informed consent. Variabel penelitian ini ialah: penelitian tentang kualitas hidup lansia pengguna gigi tiruan. Penilaian kualitas hidup diukur berdasarkan tiga dimensi kualitas hidup dengan menggunakan kuesioner Getiatric Oral Health Assesment Index (GOHAI) yaitu dimensi keterbatasan fungsi, nyeri dan ketidaknyamanan, serta aspek psikososial. Kuesioner GOHAI merupakan salah satu instrumen untuk mengukur kualitas hidup yang berhubungan dengan rongga mulut pada lansia, telah banyak digunakan di berbagai negara, serta sudah divalidasi. Nilai 1 untuk jawaban yang tidak pernah, nilai 2 untuk jawaban yang terkadang, dan nilai 3 untuk jawaban yang tidak pernah. Jumlah ini dikategorikan menjadi kategori baik, sedang dan buruk.

Untuk memperoleh penilaian setiap dimensi berdasarkan GOHAI yaitu dengan 
merata-ratakan skor dari 3 pertanyaan pada masing-masing dimensi. Penilaian kualitas hidup secara keseluruhan diperoleh dengan merata-ratakan seluruh skor dimensi GOHAI. Cara menghitung skor masingmasing pertanyaan yaitu dengan mengalikan jumlah responden yang menjawab sesuai dengan pilihan alternatif jawaban dengan nilai masing-masing alternative jawaban. Jumlah skor tertinggi $77 \times 3=231$ dan jumlah skor terendah $77 \times 1=77$ dengan nilai range 51,33 diperoleh dari pengurangan skor tertnggi dengan skor terendah lalu dibagi 2. Kategori hasil penilaian ialah sebagai berikut: Kategori baik, skor 77128,33 ; kategori sedang, skor $>128,33$ 179,66; dan kategori buruk, skor $>179-231$. Data hasil pengukuran secara kontinum terlihat seperti di bawah ini:

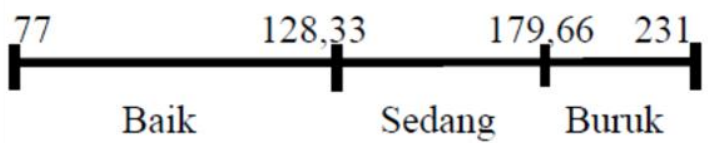

\section{HASIL PENELITIAN}

Desa Toulimembet merupakan salah satu desa yang terdiri dari 13 desa di Kecamatan Kakas, Kabupaten Minahasa, Sulawesi Utara. Jumlah penduduk di Desa Toulimembet yaitu 1.084 jiwa dengan jumlah lansia sebanyak 195 jiwa. Berdasarkan hasil penelitian yang telah dilakukan pada masyarakat lansia di Desa Toulimembet Kecamatan Kakas diperoleh 77 responden. Data mengenai karakteristik responden yaitu usia, jenis kelamin, lama pemakaian, tingkat pendidikan, jenis gigi tiruan, dan tempat pembuatan gigi tiruan.

Dalam penelitian ini terdapat total 77 responden; 54 responden $(70 \%)$ berusia 60 74 tahun dan 23 responden $(30 \%)$ yang berusia $\geq 75$ tahun. Berdasarkan jenis kelamin didapatkan 22 responden berjenis kelamin laki-laki (28\%) dan 55 responden berjenis kelamin perempuan $(72 \%)$. Lama pemakaian gigi tiruan yang terbanyak ialah 5-9 tahun pada 64 responden (84\%) sedangkan $\geq 10$ tahun pada 13 responden $(16 \%)$.

Tabel 1 menampilkan bahwa jumlah responden dengan tingkat pendidikan SD merupakan responden terbanyak berjumlah 53 lansia $(68,83 \%)$, diikuti tingkat SMP berjumlah 12 lansia $(15,5 \%)$, dan tingkat SMA berjumlah 9 lansia $(11,68 \%)$; respoden yang paling sedikit yaitu tingkat pendidikan sarjana berjumlah 3 lansia (4\%).

Tabel 1. Distribusi responden penelitian berdasarkan tingkat pendidikan

\begin{tabular}{ccc}
\hline Pendidikan & n & \% \\
\hline SD & 53 & 68,83 \\
SMP & 12 & 15,5 \\
SMA & 9 & 11,68 \\
Sarjana & 3 & 4 \\
Total & 77 & 100 \\
\hline
\end{tabular}

Tabel 2 menunjukkan bahwa yang terbanyak yaitu responden pengguna GTSL yang berjumlah 57 lansia (74\%) dan yang paling sedikit yaitu responden pengguna GTP berjumlah 20 lansia (26\%).

Tabel 2. Distribusi responden penelitian berdasarkan jenis gigi tiruan

\begin{tabular}{ccc}
\hline Jenis Gigi Tiruan & N & \% \\
\hline GTSL & 57 & 74 \\
GTP & 20 & 26 \\
Total & 77 & 100 \\
\hline
\end{tabular}

Tabel 3 memperlihatkan bahwa responden yang pembuatan gigi tiruannya dibuatkan oleh dokter gigi berjumlah 23 responden dengan persentase $30 \%$, pada pembuatan gigi tiruan oleh perawat terdapat 42 responden atau yang paling banyak dengan persentase $55 \%$ dan pembuatan gigi tiruan oleh tukang gigi berjumlah 12 responden dengan persentase $15 \%$.

Tabel 3. Distribusi responden penelitian berdasarkan tempat pembuatan gigi tiruan

\begin{tabular}{ccc}
\hline $\begin{array}{c}\text { Tempat pembuatan } \\
\text { gigi tiruan }\end{array}$ & n & \% \\
\hline Dokter gigi & 23 & 30 \\
Perawat gigi & 42 & 55 \\
Tukang gigi & 12 & 15 \\
Total & 77 & 100 \\
\hline
\end{tabular}


Tabel 4 menunjukkan bahwa responden terbanyak menyatakan tidak pernah membatasi jumlah makanan untuk dikonsumsi (33 responden); terkadang mengalami masalah atau mengunyah (30 responden); dan tidak pernah mengalami kesulitan berbicara (46 responden)

Tabel 5 menunjukkan bahwa responden terbanyak menyatakan tidak pernah mengonsumsi obat-obatan untuk menghilangkan rasa sakit (35 responden); tidak pernah mengalami merasa tidak nyaman (37 responden); dan tidak pernah sensitif terhadap makanan (35 responden).

Tabel 6 menunjukkan bahwa responden terbanyak menyatakan tidak pernah membatasi diri saat menggunakan gigi tiruan (39 responden); tidak pernah merasa cemas/kuatir (32 responden); dan tidak pernah untuk tidak percaya diri saat memakai gigi tiruan (30 responden).

Tabel 7 menunjukkan bahwa hasil pengukuran dimensi kualitas hidup seluruh dimensi memperoleh skor rerata sebesar 169,88 yang tergolong kategori cukup baik.

Tabel 4. Distribusi frekuensi kualitas hidup responden berdasarkan penilaian dimensi fungsi fisik

\begin{tabular}{cllccc}
\hline \multirow{2}{*}{ No } & & \multicolumn{3}{c}{ Altenatif Jawaban } & \multirow{2}{*}{ Nilai Skor } \\
& & S & T & TP & \\
\hline 1 & Membatasi jumlah makanan & 17 & 27 & 33 & 170 \\
2 & Mengalami masalah/mengunyah & 20 & 30 & 27 & 161 \\
3 & Kesulitan berbicara & 11 & 20 & 46 & 189 \\
& Skor rerata & & & & 173,33 \\
\hline
\end{tabular}

Ket: S, sering; T, terkadang; TP, tidak pernah

Tabel 5. Distribusi frekuensi kualitas hidup responden berdasarkan penilaian dimensi nyeri dan ketidaknyamanan.

\begin{tabular}{|c|c|c|c|c|c|}
\hline \multirow{2}{*}{ No } & \multirow{2}{*}{ Pertanyaan } & \multicolumn{3}{|c|}{ Altenatif Jawaban } & \multirow{2}{*}{ Nilai Skor } \\
\hline & & $\mathbf{S}$ & $\mathbf{T}$ & $\mathbf{T P}$ & \\
\hline 1 & Mengonsumsi obat-obatan & 15 & 27 & 35 & 174 \\
\hline 2 & Merasa tidak nyaman & 12 & 21 & 37 & 165 \\
\hline 3 & Sensitif terhadap makanan & 20 & 21 & 35 & 169 \\
\hline & Skor rerata & & & & 170 \\
\hline
\end{tabular}

Ket: S, sering; T, terkadang; TP, tidak pernah

Tabel 6. Distribusi frekuensi kualitas hidup berdasarkan penilaian dimensi aspek psikososial.

\begin{tabular}{|c|c|c|c|c|c|}
\hline \multirow{2}{*}{ No } & \multirow{2}{*}{ Pertanyaan } & \multicolumn{3}{|c|}{ Altenatif Jawaban } & \multirow{2}{*}{ Nilai Skor } \\
\hline & & $\mathbf{S}$ & $\mathbf{T}$ & TP & \\
\hline 1 & Membatasi diri & 17 & 21 & 39 & 174 \\
\hline 2 & Cemas/khawatir & 20 & 25 & 32 & 166 \\
\hline 3 & Tidak percaya diri & 27 & 20 & 30 & 157 \\
\hline & Skor rerata & & & & 166,33 \\
\hline
\end{tabular}

Ket: S, sering; T, terkadang; TP, tidak pernah

Tabel 7. Distribusi frekuensi kualitas hidup responden berdasarkan penilaian seluruh dimensi kualitas hidup.

\begin{tabular}{clc}
\hline No & \multicolumn{1}{c}{ Dimensi kualitas hidup } & Skor rerata per dimensi \\
\hline 1 & Fungsi fisik & 173,33 \\
2 & Nyeri dan ketidaknyamanan & 170 \\
3 & Aspek psikosial & 166,33 \\
& Skor rerata dimensi kualitas hidup & 169,88 \\
\hline
\end{tabular}




\section{BAHASAN}

Hasil penelitian ini mendapatkan bahwa responden terbanyak ialah pengguna gigi tiruan pada kelompok usia 60-74 tahun. Hal ini menunjukkan bahwa kelompok usia 60 tahun ke atas banyak yang telah kehilangan gigi yaitu sebesar $70 \%$. Organ tubuh termasuk gigi geligi sangat penting bagi manusia dan juga sangat rentan terhadap kerusakan dikarenakan sering digunakan atau difungsikan. Semakin bertambahnya usia, maka kondisi jaringan pasti mengalami penurunan, termasuk jaringan di dalam rongga mulut. ${ }^{8,9}$

Responden pada penelitian ini seluruhnya berjumlah 77 responden, dan yang terbanyak ialah berjenis kelamin perempuan. Hasil ini sejalan dengan penelitian yang dilakukan oleh Massie ${ }^{10}$ pada tahun 2012 yang menunjukkan bahwa persentase pengguna gigi tiruan berjenis kelamin perempuan di salah satu kecamatan di Sulawesi Utara lebih banyak dibandingkan laki-laki.

Hasil penelitian menunjukkan bahwa sebagian besar responden menempuh pendidikan tingkat SD diikuti dengan tingkat pendidikan SMA dan SMP serta sebagian dari tingkat sarjana. Responden dengan pendidikan tingkat SD mencapai persentase sebesar $68,83 \%$, jauh lebih tinggi daripada tingkat pendidikan SMA, SMP, dan Sarjana (Tabel 1). Walaupun demikian tingkat kesadaran dan kepedulian responden tidak hanya dilihat dari latar belakang pendidikan. Adanya pemahaman tentang pentingnya keberadaan gigi berkaitan dengan fungsinya dan penampilan menyebabkan responden yang mengalami kehilangan gigi memutuskan untuk memakai gigi tiruan. Hasil ini sejalan dengan penelitian yang dilakukan oleh Siagian et $\mathrm{al}^{11}$ yang menyatakan bahwa hal tersebut mungkin disebabkan oleh pengalaman individu dan latar belakang kultural serta kemampuan beradaptasi yang memiliki peran penting dari pada pendidikan formal.

Hasil penelitian mendapatkan bahwa responden terbanyak menggunakan gigi tiruan dalam kurun waktu 5-9 tahun. Sebanyak 64 responden (84\%) mengguna- kan GTSL dan 13 responden menggunakan GTP (16\%) (Tabel 2). Hasil ini menunjukkan bahwa responden pengguna gigi tiruan GTSL dan GTP tidak berimbang. Pada lansia, kehilangan gigi bukan saja dilihat dari perilaku menjaga kesehatan gigi dan mulut tetapi juga dipengaruhi faktor usia dan kondisi sistemik. Semakin bertabahnya usia maka risiko kehilangan sangat besar, demikian halnya dengan kondisi sistemik pada lansia, salah satunya ialah penyakit diabetes melitus yang berdampak pada kehilangan gigi sehingga membutuhkan penggunaan gigi tiruan.

Hasil penelitian menunjukkan bahwa pemasangan gigi tiruan paling banyak dilakukan oleh perawat gigi $(55 \%)$ diikuti pemasangan oelh dokter gigi (30\%), dan tukang gigi (15\%) (Tabel 3). Lansia pada penelitian ini cenderung memilih perawat gigi untuk pembuatan gigi tiruan dikarenakan harga yang tidak berbeda jauh dari dokter gigi dan rasa percaya untuk memasang gigi tiruan pada perawat gigi. Sebagian responden memilih dokter gigi karena tingkat pengetahuan dan kesadaran akan kesehatan gigi dan mulut. Terdapat 12 responden yang masih memilih ke tukang gigi dengan alasan harga yang sangat murah tetapi sebagian besar responden penelitian ini sudah menyadari bahwa tukang gigi bukanlah merupakan sebuah profesi yang sama halnya dengan dokter gigi.

Dalam penggunaan gigi tiruan, seseorang akan membatasi jumlah makanan karena merasa tidak nyaman saat mengunyah dan menelan serta kesulitan berbicara. Diharapkan penggunaan gigi tiruan tersebut dapat membantu atau mengembalikan fungsi yang hilang, Hasil penelitian ini mendapatkan bahwa sebagian besar responden tidak pernah membatasi jumlah makanan, sebagian terkadang merasa mengalami masalah saat mengunyah, serta sebagian besar tidak merasa ada gangguan saat makan dan berbicara (Tabel 4). Hal ini disebabkan sebagian besar responden cukup puas dengan gigi tiruannya. Hasil penilaian kualitas hidup lansia berdasarkan dimensi fungsi fisik memperoleh skor rerata 173,33 yang tergolong kategori cukup baik. 
Adanya gangguan di dalam rongga mulut berupa rasa sakit ketika memakai gigi tiruan disebabkan karena desain gigi tiruan yang kurang baik. Hal ini dapat menimbulkan rasa ketidaknyamanan pada responden pengguna gigi tiruan serta keadaan gusi yang sensitif terhadap makanan dan minuman baik panas, hangat, dan dingin. Hasil penelitian penilaian kualitas hidup dimensi nyeri dan ketidaknyamanan mendapatkan bahwa sebagian besar responden merasa nyaman, dan sebagian besar tidak pernah mengalami nyeri saat makan atau rasa sensitif dalam mulut, serta tidak menggunakan obat-obat untuk menghilangkan rasa sakit dengan skor rerata 170 yang tergolong kategori cukup baik (Tabel 5).

Hasil penelitian mengenai kualitas hidup lansia berdasarkan aspek psikososial menunjukkan bahwa dari 77 responden, terdapat 39 responden $(50,64 \%)$ tidak membatasi diri, yang tidak pernah mengalami kecemasan atau kuatir sebanyak 32 responden $(41,55 \%)$, serta yang percaya diri sebanyak 30 responden $(38,96 \%)$. Hal ini disebabkan karena responden cukup mampu menyesuaikan diri dan merasa nyaman dengan penggunaan gigi tiruan sehingga ketika digunakan untuk mengunyah dan berbicara di depan umum responden tidak terlalu merasa cemas atau kuaatir. Kenyamanan ini dipengaruhi oleh kualitas gigi tiruan yang dibuat sehingga pengguna merasa percaya diri. Gigi tiruan yang memiliki kualitas baik mampu mengembalikan fungsi akibat kehilangan gigi. Hasil dari penilaian kualitas hidup lansia berdasarkan dimensi aspek psikososial memperoleh skor rerata 166,33 yang tergolong kategori cukup baik.

Hasil penilaian keseluruhan dimensi skala GOHAI mengenai fungsi fisik, nyeri dan ketidaknyamanan, serta aspek psikososial tergolong cukup baik dengan skor rerata 169,88. Penilaian ini menunjukkan bahwa kualitas hidup lansia pengguna gigi tiruan memiliki kualitas hidup yang cukup baik. Hal ini selaras dengan penelitian Hussain et al $^{12}$ yang melaporkan bahwa penggunaan gigi tiruan penting untuk mendapatkan kualitas hidup yang lebih baik dan secara langsung memiliki dampak positif terhadap aktivitas sosial, mental dan psikologis.

\section{SIMPULAN}

Berdasarkan hasil penelitian ini dapat disimpulkan bahwa kualitas hidup lansia pengguna gigi tiruan di Desa Toulimembet Kecamatan Kakas tergolong cukup baik.

Bagi institusi pemerintah dalam hal ini Dinas Kesehatan dan puskesmas disarankan agar dapat menggunakan hasil penelitian ini untuk kepentingan promosi kesehatan mengenai pentingnya penggunaan gigi tiruan dalam meningkatkan kualitas hidup lansia. Para lansia yang kehilangan gigi dapat termotivasi menggunakan gigi tiruan untuk meningkatkan kualitas hidup. Selain itu, perlu dilakukan penelitian sejenis dengan melibatkan populasi yang lebih luas untuk memperoleh hasil yang lebih mendekati kondisi sebenarnya.

\section{DAFTAR PUSTAKA}

1. Departemen Sosial Republik Indonesia. Undang-Undang Republik Indonesia Nomor 13 Tahun 1998 tentang kesejahteraan lanjut usia. 2006; p. 2-3

2. Othman WW, Muttalib KA, Bakri R, Doss JG, Jaafar N, Sailer NC, et al. Validation of the Geriatric Oral Health Assessment Index (GOHAI) in the Malay Language. J Pub Health Dent. 2006;66(3):199- 204.

3. Pusat Data dan Informasi Kementerian Kesehatan RI. Gambaran Kesehatan Lanjut Usia di Indonesia. Buletin Jendela Data dan Informasi Kesehatan. 2013;Semester I:2.

4. Martono H, Pranaka K. Buku Ajar Geriatri (Ilmu Kesehatan Lansia). Jakarta: Balai Penerbit FK UI, 2004; p. 7-19, 72-9, 694-704, 711-3, 804-10.

5. Tarigan S. Pasien prostodonsia lanjut usia beberapa pertimbangan dalam perawatan. Medan: Universitas Sumatra Utara; 2005.

6. World Health Organization. WHOOQL: Measuring quality of life. 1997. Available from: https://www.who.int/ mental_health/media/68.pdf.

7. Wilanisa ARP, Permana I. Hubungan antara fungsi keluarga dan kualitas hidup lan- 
sia. Mutiara Medika. 2011;11(1):1-7.

8. Thahja IN, Ghani L. Status kesehatan gigi dan mulut ditinjau dari faktor individu pengunjung puskesmas DKI Jakarta tahun 2007. Buletin Penelitian Kesehatan. 2010;38(2):52-66.

9. But AM, Bilahlahmed, Parveen N. Oral health related quality of life in complete denture. Pakistan Oral and Dental Journal. 2009:29(2):136.

10. Massie N. Kualitas hidup manusia lanjut usia pengguna gigi tiruan di Kecamatan Wanea [Skripsi]. Manado: Fakultas
Kedokteran Universitas Sam Ratulangi; 2016.

11. Siagian KV, Mintjelungan CN. Analisis kualitas hidup pasien usia produktif pengguna gigi tiruan sebagian lepasan di RSGM PSPDG Fakultas Kedokteran Universitas Sam Ratulangi Manado. eGigi. 2017;5(2):208-15.

12. Hussain SZ, Shujaat NG, Irid SH. Oral health related quality of life (OHRQoL) in 40 to 70 years. Pak Oral Dental J. 2010:30(2):530. 